\title{
Early ontogeny of the Cambrian trilobite Sao hirsuta from the Skryje-Týřovice Basin, Barrandian area, Czech Republic
}

\author{
LUKÁŠ LAIBL, OldŘICH FATKA, CATHERINe CRÔNIER \& PETR BUDIL
}

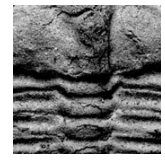

\begin{abstract}
Preservation of ontogenetic stages of trilobites from the Cambrian of the Skryje-Týřovice Basin (Barrandian area) has been known from several localities in the upper part of the Buchava Formation. The most complete information on exoskeletal changes during ontogeny was based on material assigned by Barrande (1852) to Sao hirsuta. Based on quantitative methods and detailed study of the morphology of the exoskeleton, we recognize three protaspid and two early meraspid instars of Sao hirsuta. We also describe the protaspid stages of two indeterminate taxa of Ptychopariida, one originally determined as the protaspides of Sao hirsuta and the other referred to by Rủžička (1943) as "Barrande's larva". Protaspides of Sao hirsuta have an adult-like morphology, and their presumed benthic mode of life is consistent with the restricted palaeogeographic distribution of this genus. • Key words: trilobites, ontogeny, Skryje-Týřovice Basin, Buchava Formation, Barrandian area, Cambrian.
\end{abstract}

LAIBL, L., FATKA, O., CRÔNIER, C. \& Budil, P. 2014. Early ontogeny of the Cambrian trilobite Sao hirsuta from the Skryje-Týřovice Basin, Barrandian area, Czech Republic. Bulletin of Geosciences 89(2), 293-309 (8 figures, 4 tables). Czech Geological Survey, Prague, ISSN 1214-1119. Manuscript received April 4, 2013; accepted in revised form October 11, 2013; published online March 17, 2014; issued May 19, 2014.

Lukáš Laibl \& Oldřich Fatka, Charles University, Faculty of Science, Institute of Geology and Palaeontology, Albertov 6, 12843 Prague 2, Czech Republic; lukaslaibl@gmail.com, fatka@natur.cuni.cz•Catherine Crônier, Université Lille 1, UFR Sciences de la Terre, UMR 8217 Géosystèmes, 59655 Villeneuve d'Ascq, France; catherine.cronier@univ-lille1.fr• Petr Budil, Czech Geological Survey, Klárov 3, Praha 1, 11821 Czech Republic; petr.budil@geology.cz.

A short preliminary announcement and diagnosis of a spectacular solenopleurid trilobite Sao were published by Barrande (1846). A more comprehensive account was provided by Hawle \& Corda (1847) who, however, did not use Barrande's generic name because they considered it to be preoccupied. Unfortunately, these two preliminary studies contained numerous mistakes criticized by Barrande (1852), who provided the first thorough study of the ontogeny of Sao and several other trilobites. New data on the early ontogeny of Sao hirsuta was provided by Růžička (1943), based on large new collections of immature specimens including anaprotaspides. He also distinguished the so-called "Barrande's larva", a protaspid stage of uncertain affinity (Růžička 1943, text-figures on pages 14 and 31). Whittington (1957) argued that the smallest stages described by Růžička (1943, pl. 4, figs 7, 8, pl. 5, fig. 5) probably belong to "Barrande's larva" rather than to S. hirsuta. In the following year, Šnajdr (1958) summarized all earlier data on Cambrian trilobites of the Barrandian area, including the ontogeny of $S$. hirsuta, provided new observations and illustrated many early ontogenetic specimens of the species. Since then, no new information on the ontogeny of
S. hirsuta or any other trilobites from the Skryje-Týřovice Basin have been published, with the exception of a short comment by Valíček \& Šarič (2001) on Luhops expectans (Barrande, 1852).

Recent methods of investigation of exceptionally preserved fossil material combined with intensive study of trilobite ontogeny have made it possible to evaluate trilobite ontogenies more comprehensively and to compare them with those of other arthropods. Ontogenetic data have been important for our understanding of the palaeobiogeographic distribution of trilobites (Chatterton \& Speyer 1989), their systematics (Fortey 1990, 2001), and their phylogenetic relationships (Edgecombe et al. 1988, Fortey \& Chatterton 1988, Park \& Choi 2009). They have also enabled the exploration of topics as different as survivorship during extinction events (Chatterton \& Speyer 1989, Lerosey-Aubril \& Feist 2005) and the evolution of trilobite body patterning (Hughes 2007, Feist \& Lerosey-Aubril 2008).

The objectives of the present study are: (1) to investigate the immature specimens assigned to $S$. hirsuta by previous authors, using modern techniques (e.g., scanning 

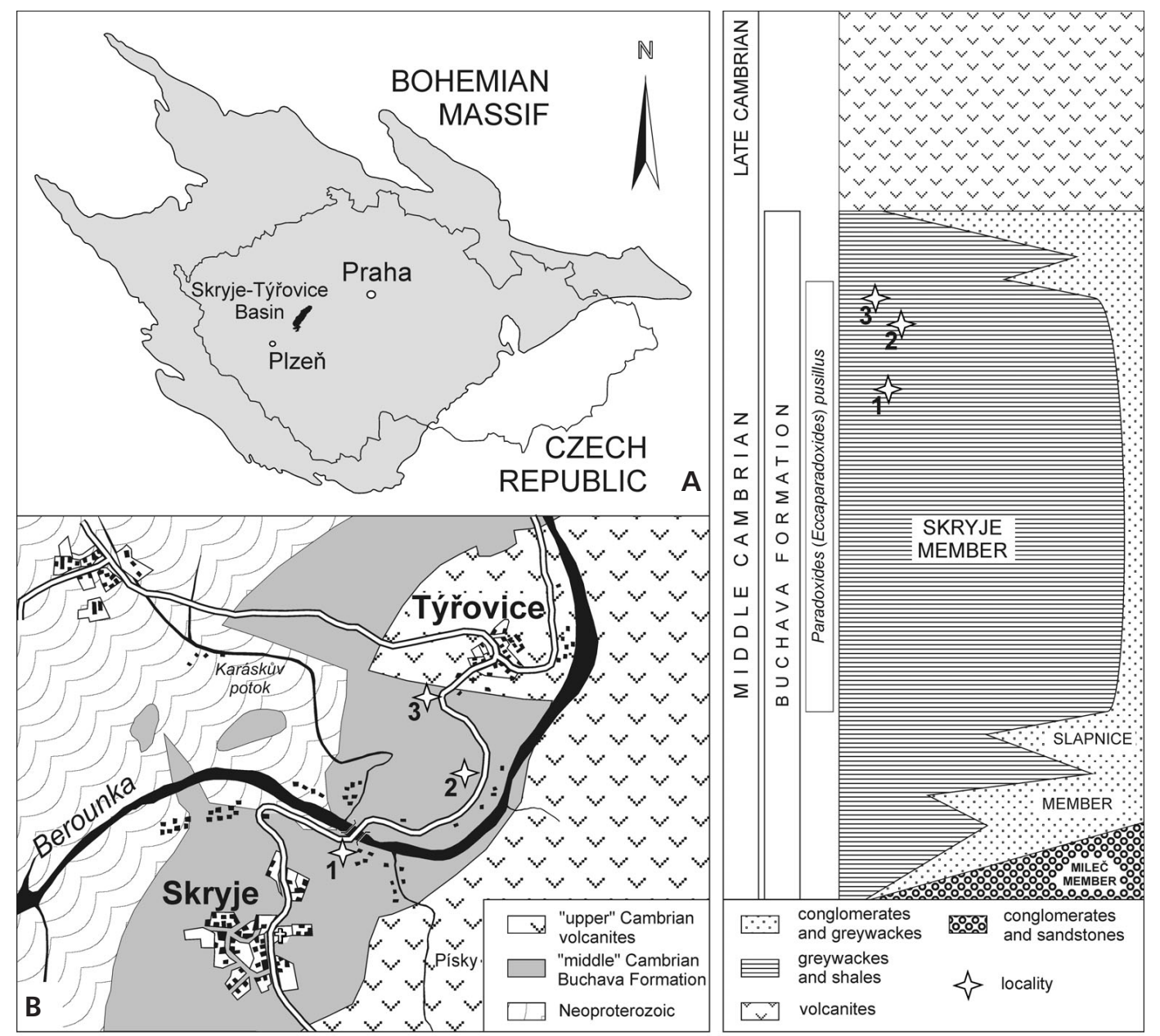

Figure 1. Geological setting. • A - map of the Bohemian Massif (shaded) showing the Czech Republic and the Cambrian of the Skryje-Týřovice Basin. - B - Cambrian of the Skryje-Týřovice Basin with location of the following fossil sites in the Buchava Formation: Skryje - Luh (1), Týřovice - Pod hruškou (2) and Týrovice - Lủmek (3); geology modified after Mašek et al. (1997). • C - stratigraphic positions of the three localities within the Buchava Formation of the Skryje-Týřovice Basin; stratigraphy after Fatka et al. (2011b).

electron microscopy, quantitative methods); (2) to assess whether the specimens are all truly conspecific; (3) to provide accurate descriptions of the morphological changes during the early ontogeny of S. hirsuta; and (4) to infer life-history strategy and its possible implication for the palaeobiogeographic distribution of this species.

\section{Geological setting}

The Cambrian Buchava Formation (Fatka et al. 2011b) consists of about $200 \mathrm{~m}$ of fossiliferous siliciclastic sediments (fine shales and graywackes with subordinate lenses of sandstones and conglomerates) in the Skryje-Týřovice Basin, situated northeast of the town of Plzeň (Fig. 1A). The formation, which crops out in a narrow zone around the middle course of the Berounka River, unconformably overlies slightly metamorphosed Neoproterozoic rocks and is overlain by Furongian to earliest Ordovician extru- sive rocks (dacites, andesites and rhyolites) of the Krrivoklát-Rokycany Complex (Havlíček 1971, Drost et al. 2004).

The basal part of the Buchava Formation is composed of poorly fossiliferous, white to grey conglomerates and sandstones containing only fragmentary remains of trilobites, brachiopods and gastropods (Havlíček 1971). This sequence is usually overlain by darker conglomerates associated with greyish green graywackes and shales with fragmentary but locally common trilobites and brachiopods (e.g. Mergl \& Kordule 2008) and some exceptionally preserved fossils such as graptoloids and Wiwaxia (Maletz et al. 2005, Fatka et al. 2011a). The sequence of graywackes and clayey shales with occasional silty to sandy intercalations is the most widespread lithofacies, reaching a thickness of nearly $200 \mathrm{~m}$ in the north-eastern part of the basin. A rich assemblage of well-preserved fossils including trilobites, agnostids, echinoderms, brachiopods, hyolithids, molluscs, 
sphenothallids, organic-walled microfossils and ichnofossils has been recorded from numerous outcrops of these fine-grained sediments (e.g. Šnajdr 1958, Lefebvre \& Fatka 2003, Álvaro et al. 2004, Fatka 2004, Fatka \& Szabad 2011). In the northeastern part of the Skryje-Týrrovice Basin, several tongue-like bodies of dark conglomerate are developed in the upper part of the Buchava Formation. Fine shales overlying and underlying these conglomerates are exposed at several outcrops. An abundant and diverse fauna was collected at three of these outcrops, at Skryje - Luh, Týřovice - Pod hruškou and Týřovice - Lůmek (Fig. 1). Most of the growth stages of Sao hirsuta described by Hawle \& Corda (1847), Barrande (1852), Růžička (1943), Whittington (1957) and Šnajdr (1958), as well as by us in the present study, came from the Týřovice - Pod hruškou locality (see Fatka 2004). The specimens from Týřovice - Pod hruškou were supplemented in our study by less well preserved ones that are rare at the other two outcrops.

\section{Material and methods}

Material. - The specimens, preserved as internal and external moulds in very fine-grained shales, were either coated with ammonium chloride and photographed under an optical microscope (Nikon SMZ 1500, Olympus SZX 12) and/or photographed using a scanning electron microscope in a low vacuum mode (JEOL-6380 LV, Hitachi S-3700N). Drawings were produced from the photographs. The specimens are housed in the National $\mathrm{Mu}-$ seum, Prague (NM), the Czech Geological Survey (CGS), Prague, and in the Museum of Dr Bohuslav Horák at Rokycany (MBHR).

Biometric measurements. - One hundred and one of the best preserved protaspid and early meraspid specimens were selected for biometric studies (Tables 1-3). The maximum length and width of the exoskeleton (Fig. 2), excluding spines, were measured using optical image analyzer TpsDig2 (Rohlf 2006a).

Landmarks and centroid size. - Landmark-based geometric morphometrics were performed to obtain the centroid size of protaspides of $S$. hirsuta. Three landmarks (all type 2 of Bookstein 1991) were selected on the protaspid exoskeleton (see Fig. 2). The 2D projections of landmarks were obtained using TpsDig2, and the centroid size calculated using TpsRelw (Rohlf 2006b).

Graphs. - All bivariate plots and the frequency histogram, as well as the linear regression, linear correlation and the $p$ value, have been made using the PAST package (Hammer et al. 2001).

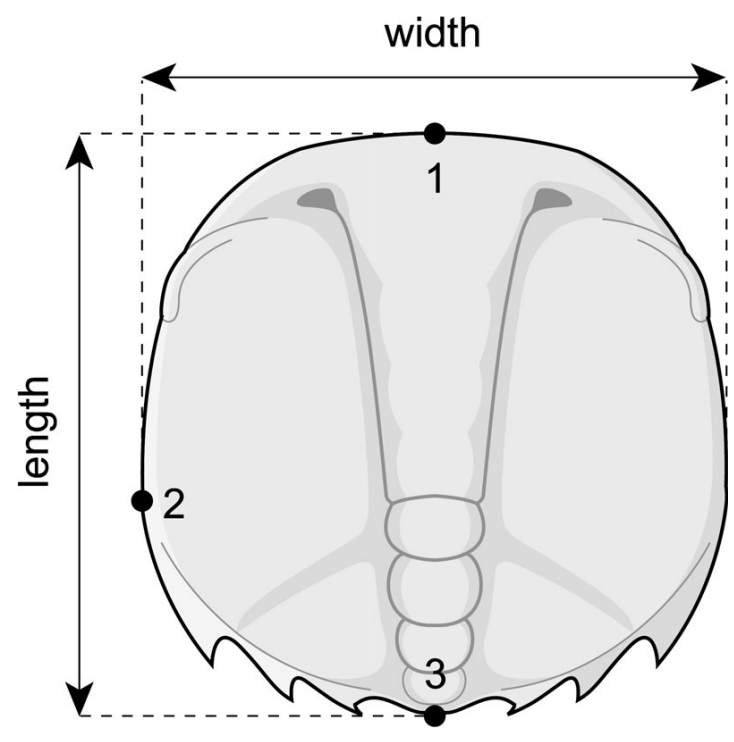

Figure 2. Measured parameters. The landmarks are defined as: 1) anteriormost point of the exoskeleton; 2) maximum lateral extent of the exoskeleton; 3) posterior end of the exoskeleton.

Growth. - For S. hirsuta, four growth metrics have been calculated: Dyar's index $(D i)$, the average per-moult increment $(A G I)$, the average per-moult growth rate $(A G R)$ and the index of conformity to Dyar's rule (IDC). Dyar's index is a post-moult $v s$. pre-moult size ratio between the two successive instars (Dyar 1890). For detailed calculation of AGI, AGR and IDC, see Fusco et al. (2011).

\section{Systematic palaeontology}

Terminology. - Morphological terminology generally follows Whittington \& Kelly (1997), with the following exceptions. The terms anaprotaspis, metaprotaspis and paraprotaspis (sensu Beecher 1895) are not used, following the recommendation of Chatterton \& Speyer (1997); protaspid instars are instead referred to as stages 1, 2 and 3, as in Lee $\&$ Chatterton (2005). The terminology of the posterior cranidial border furrow and posterior cephalic marginal furrow follows Lee \& Chatterton (2005). Terminology of the post-cephalic part of the exoskeleton during ontogeny is based on Hughes et al. (2006). The following abbreviations are used: P1, P2 and P3 for protaspid stages 1, 2 and 3; M1-4 and M1-5 for meraspid degree 1 with respectively four or five segments in the meraspid pygidium.

Order Ptychopariida Swinnerton, 1915

Family Solenopleuridae Angelin, 1854

Subfamily Solenopleuropsinae Thoral, 1947

Remarks. - We provisionally follow Álvaro \& Vizcaïno (1997) in regarding the subfamily Saoinae Hupé, 1953 as invalid. 
Table 1. Dimensions and trunk segment numbers of protaspid and early meraspid stages of Sao hirsuta Barrande, 1846.

\begin{tabular}{|c|c|c|c|c|c|c|}
\hline Institution & Number & Stage & $\begin{array}{l}\text { Width } \\
(\mathrm{mm})\end{array}$ & $\begin{array}{l}\text { Length } \\
(\mathrm{mm})\end{array}$ & Centroid size & $\begin{array}{c}\text { Segment } \\
\text { number }\end{array}$ \\
\hline CGS & 3173 & $\mathrm{P} 1$ & 0.66 & 0.62 & 5,11E-01 & $?$ \\
\hline CGS & 3229 & $\mathrm{P} 1$ & 0.68 & 0.63 & $5,26 \mathrm{E}-01$ & $?$ \\
\hline NM & L3550 & $\mathrm{P} 1$ & 0.7 & 0.67 & $5,48 \mathrm{E}-01$ & $?$ \\
\hline NM & L3555 & $\mathrm{P} 1$ & 0.7 & 0.67 & $5,47 \mathrm{E}-01$ & $?$ \\
\hline NM & L3686 & $\mathrm{P} 1$ & 0.76 & 0.68 & 5,74E-01 & $?$ \\
\hline NM & L3689 & $\mathrm{P} 1$ & 0.72 & 0.69 & $5,68 \mathrm{E}-01$ & $?$ \\
\hline NM & L3690 & $\mathrm{P} 1$ & 0.72 & 0.66 & $5,51 \mathrm{E}-01$ & $?$ \\
\hline NM & L3691 & $\mathrm{P} 1$ & 0.78 & 0.67 & $5,69 \mathrm{E}-01$ & $?$ \\
\hline NM & L3692 & $\mathrm{P} 1$ & 0.74 & 0.62 & $5,39 \mathrm{E}-01$ & $?$ \\
\hline NM & L3698 & $\mathrm{P} 1$ & 0.72 & 0.71 & $5,83 \mathrm{E}-01$ & $?$ \\
\hline NM & L3704 & $\mathrm{P} 1$ & 0.72 & 0.71 & $5,78 \mathrm{E}-01$ & $?$ \\
\hline NM & L3705 & $\mathrm{P} 1$ & 0.72 & 0.61 & $5,21 \mathrm{E}-01$ & $?$ \\
\hline NM & L3708 & $\mathrm{P} 1$ & 0.74 & 0.63 & $5,36 \mathrm{E}-01$ & $?$ \\
\hline NM & L3718 & P1 & 0.7 & 0.7 & $5,70 \mathrm{E}-01$ & $?$ \\
\hline CGS & 3164 & $\mathrm{P} 2$ & 0.86 & 0.77 & $6,60 \mathrm{E}-01$ & 3 \\
\hline CGS & 3490 & $\mathrm{P} 2$ & 0.8 & 0.72 & $6,13 \mathrm{E}-01$ & 3 \\
\hline CGS & 3521 & $\mathrm{P} 2$ & 0.76 & 0.76 & $6,28 \mathrm{E}-01$ & 3 \\
\hline MBHR & 89959 & $\mathrm{P} 2$ & 0.88 & 0.82 & $6,84 \mathrm{E}-01$ & 3 \\
\hline MBHR & 89992 & $\mathrm{P} 2$ & 0.84 & 0.86 & 7,02E-01 & 3 \\
\hline NM & L12500 & $\mathrm{P} 2$ & 0.88 & 0.75 & $6,48 \mathrm{E}-01$ & 3 \\
\hline NM & L12501 & $\mathrm{P} 2$ & 0.8 & 0.76 & $6,28 \mathrm{E}-01$ & 3 \\
\hline NM & L19012 & $\mathrm{P} 2$ & 0.92 & 0.83 & 7,03E-01 & 3 \\
\hline NM & L3534 & $\mathrm{P} 2$ & 0.84 & 0.82 & $6,74 \mathrm{E}-01$ & 3 \\
\hline NM & L3537 & $\mathrm{P} 2$ & 0.84 & 0.85 & 7,00E-01 & 3 \\
\hline NM & L3539 & $\mathrm{P} 2$ & 0.76 & 0.83 & $6,71 \mathrm{E}-01$ & 3 \\
\hline NM & L3544 & $\mathrm{P} 2$ & 0.82 & 0.81 & $6,65 \mathrm{E}-01$ & 3 \\
\hline NM & L3546 & $\mathrm{P} 2$ & 0.84 & 0.74 & $6,29 \mathrm{E}-01$ & 3 \\
\hline NM & L3548 & $\mathrm{P} 2$ & 0.78 & 0.79 & $6,41 \mathrm{E}-01$ & 3 \\
\hline NM & L3554 & $\mathrm{P} 2$ & 0.8 & 0.82 & $6,62 \mathrm{E}-01$ & 3 \\
\hline NM & L3566 & $\mathrm{P} 2$ & 0.84 & 0.84 & $6,90 \mathrm{E}-01$ & 3 \\
\hline CGS & MS563 & $\mathrm{P} 2$ & 0.88 & 0.82 & $6,93 \mathrm{E}-01$ & 3 \\
\hline CGS & MS564 & $\mathrm{P} 2$ & 0.82 & 0.8 & $6,60 \mathrm{E}-01$ & 3 \\
\hline CGS & 3140 & P3 & 0.94 & 0.96 & $7,68 \mathrm{E}-01$ & 4 \\
\hline
\end{tabular}

\begin{tabular}{|c|c|c|c|c|c|c|}
\hline Institution & Number & Stage & $\begin{array}{l}\text { Width } \\
(\mathrm{mm})\end{array}$ & $\begin{array}{c}\text { Length } \\
(\mathrm{mm})\end{array}$ & Centroid size & $\begin{array}{c}\text { Segment } \\
\text { number }\end{array}$ \\
\hline CGS & 3487 & P3 & 0.98 & 0.93 & 7,67E-01 & 4 \\
\hline CGS & 3505 & P3 & 0.9 & 0.93 & 7,49E-01 & 4 \\
\hline MBHR & 89940 & P3 & 1 & 0.91 & 7,60E-01 & 4 \\
\hline MBHR & 89980 & P3 & 1.1 & 1.01 & $8,48 \mathrm{E}-01$ & 4 \\
\hline MBHR & 89981 & P3 & 0.94 & 0.99 & 7,99E-01 & 4 \\
\hline MBHR & 89985 & P3 & 0.96 & 0.98 & 7,95E-01 & 4 \\
\hline NM & L19014 & $\mathrm{P} 3$ & 0.98 & 0.96 & $7,83 \mathrm{E}-01$ & 4 \\
\hline NM & L3727 & P3 & 0.92 & 0.98 & $7,83 \mathrm{E}-01$ & 4 \\
\hline NM & L3729 & $\mathrm{P} 3$ & 1.04 & 1.04 & $8,42 \mathrm{E}-01$ & 4 \\
\hline NM & L3732 & P3 & 1 & 0.98 & $8,11 \mathrm{E}-01$ & 4 \\
\hline NM & L3734 & P3 & 1.08 & 0.97 & $8,13 \mathrm{E}-01$ & 4 \\
\hline NM & L3736 & P3 & 1.06 & 1.09 & $8,86 \mathrm{E}-01$ & 4 \\
\hline NM & L3739 & P3 & 1.04 & 0.96 & 7,97E-01 & 4 \\
\hline NM & L3742 & P3 & 0.92 & 0.95 & $7,71 \mathrm{E}-01$ & 4 \\
\hline NM & L3744 & P3 & 0.96 & 1.03 & $8,24 \mathrm{E}-01$ & 4 \\
\hline NM & L3750 & P3 & 1.02 & 1.04 & $8,35 \mathrm{E}-01$ & 4 \\
\hline NM & L3752 & P3 & 0.96 & 0.99 & $8,05 \mathrm{E}-01$ & 4 \\
\hline NM & L3754 & P3 & 1.04 & 0.92 & 7,84E-01 & 4 \\
\hline NM & L3755 & P3 & 1.02 & 0.94 & $7,80 \mathrm{E}-01$ & 4 \\
\hline CGS & MS11478 & P3 & 1.04 & 1.03 & $8,42 \mathrm{E}-01$ & 4 \\
\hline CGS & MS568 & P3 & 0.92 & 0.94 & $7,47 \mathrm{E}-01$ & 4 \\
\hline CGS & MS569 & P3 & 0.9 & 1.02 & $8,10 \mathrm{E}-01$ & 4 \\
\hline CGS & MS570 & P3 & 0.94 & 0.95 & 7,72E-01 & 4 \\
\hline CGS & MS572 & P3 & 1.02 & 0.92 & $7,69 \mathrm{E}-01$ & 4 \\
\hline CGS & MS572_1 & P3 & 1.02 & 0.99 & $8,16 \mathrm{E}-01$ & 4 \\
\hline CGS & MS9536 & P3 & 1.06 & 1.08 & $8,83 \mathrm{E}-01$ & 4 \\
\hline CGS & MS9544 & P3 & 0.92 & 0.94 & 7,61E-01 & 4 \\
\hline NM & L19015 & M1-4 & 1.16 & 1.18 & - & 5 \\
\hline CGS & MS573 & M1-4 & 1.12 & 1.12 & - & 5 \\
\hline CGS & MS575 & M1-4 & 1.08 & 1.21 & - & 5 \\
\hline NM & L19016 & M1-5 & 1.22 & 1.31 & - & 6 \\
\hline CGS & MS574 & M1-5 & 1.23 & 1.37 & - & 6 \\
\hline CGS & MS579 & M1-5 & 1.24 & 1.31 & - & 6 \\
\hline
\end{tabular}

Genus Sao Barrande, 1846

[nom. conserv., non Sao Billberg, 1820; ICZN Opinion 512]

Type species. - Sao hirsuta Barrande, 1846; Buchava Formation, Drumian, Skryje-Týřovice Basin, Barrandian area, Czech Republic.

Emended diagnosis. - A genus of Solenopleuropsinae with the following combination of characters: (1) cephalic border vaulted, delimited by deep furrow; (2) glabella with three deep transverse lateral glabellar furrows and a sagittal furrow; (3) exoskeleton densely covered with tubercles and small hollow spines; (4) preglabellar field concave without any tubercles or spines.

Occurrence. - In addition to the occurrence in the SkryjeTýřovice Basin, the genus has been recorded from the Lippertsgrün Formation (Drumian) of the Franconian Forest, Germany (Sdzuy 2000) and from the middle part of the Playón Beds (Drumian?) of the Ossa-Morena Zone, Spain (Gozalo et al. 1994). 

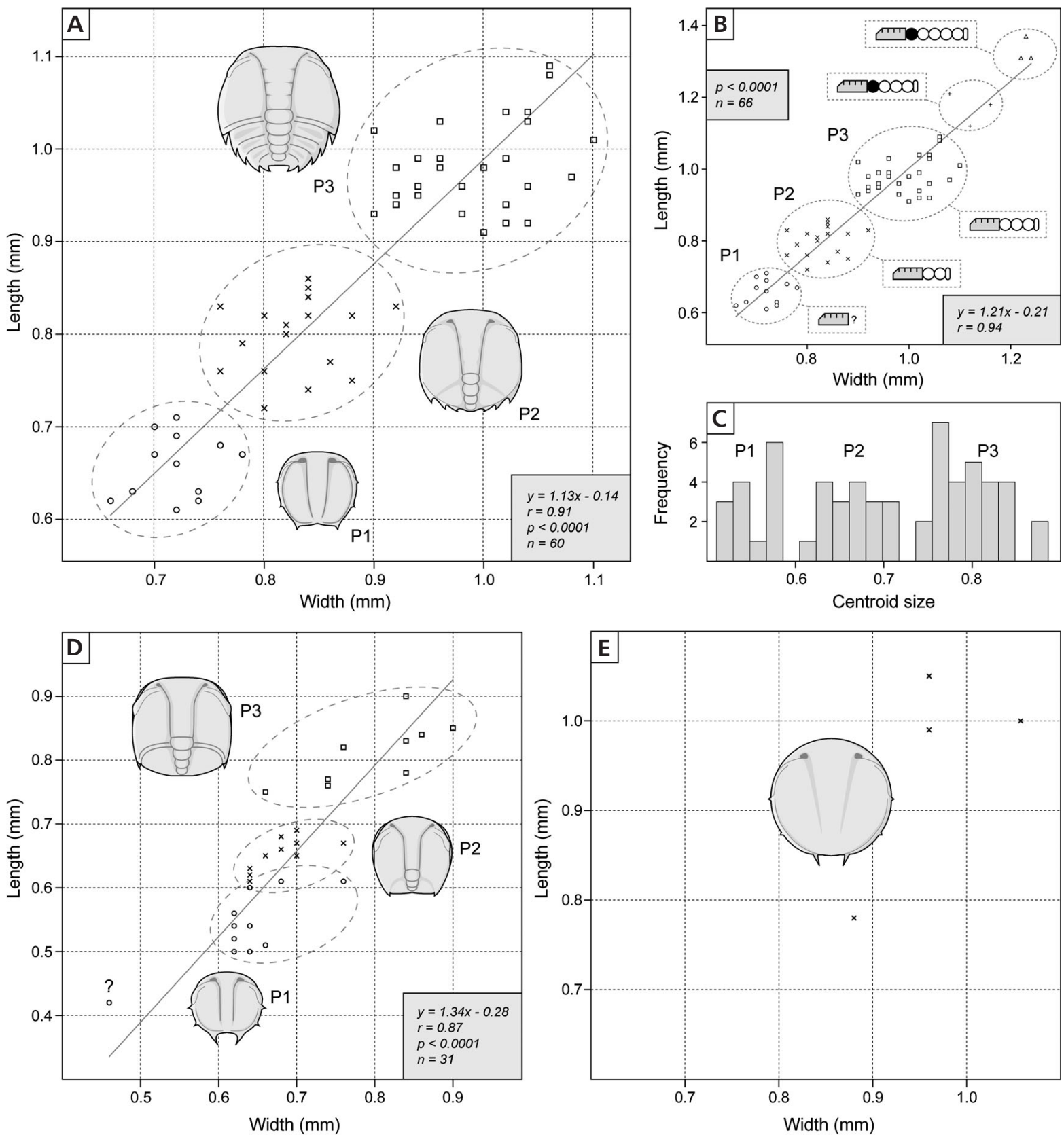

Figure 3. Graphs. $\bullet$ A - scatter plot diagram of length versus width of 60 protaspides of Sao hirsuta. $\bullet$ B - scatter plot diagram of length versus width of 60 protaspides and 6 early meraspides of Sao hirsuta. Cephala (grey pentagons), articulated segments (black circles) and fused segments (white circles) are figured. $• \mathrm{C}$ - size frequency histogram of centroid size of 60 protaspides of Sao hirsuta. $\bullet$ D - scatter plot diagram of length versus width of 31 protaspides of Ptychopariida sp. A. $\bullet$ E - scatter plot diagram of length versus width of 4 protaspides of Ptychopariida sp. B.

\section{Sao hirsuta Barrande, 1846}

Figures 4-6, 8A-F

1846 Sao hirsuta Barr.; Barrande, p. 13.

1852 Sao hirsuta Barr. - Barrande, p. 384, pl. 3, fig. 6, pl. 4, fig. 12, pl. 7, figs 1a-c, 2-32 (non pl. 7, fig. 1d, $\mathrm{e}=$ Ptychopariida sp. A).

1943 Sao hirsuta Barrande. - Růžička, p. 11, pl. 4, figs 11,
13-15, 17 (non pl. 4, figs $7-10,12,16$, pl. 5, fig. $5=$ Ptychopariida sp. A).

1957 Sao hirsuta Barrande. - Whittington, pp. 937-940, pl. 115 , figs 21,22 ; pl. 116 , figs $16,17,19$ (non pl. 116, figs 14, 15, 18, 20, 21 = Ptychopariida sp. A).

1958 Sao hirsuta Barrande. - Šnajdr, pp. 21, 23, 204-214, figs 44,45 , pl. 43, figs 7-9, 13-23, 26-33, 35 (non 
figs 1-6, 10-12, 24, 34 = Ptychopariida sp. A), pl. 44, pl. 45, figs 1-24 (see for complete synonymy prior to 1957).

1959 Sao hirsuta Barrande. - Whittington, pp. 130, 142, fig. 88.

1959 Sao hirsuta Barrande. - Poulsen, pp. 276-277, figs 204, 13.

1970 Sao hirsuta Barrande. - Horný \& Bastl, pp. 157-164, pl. 4 , fig. 4.

1971 Sao hirsuta Barrande. - Havlíček, p. 35.

1988 Sao hirsuta Barrande. - Whittington, pp. 591, 592, fig. 13, pl. 53, figs 5-7.

1990 Sao hirsuta Barrande. - Šnajdr, pp. 10, 26, 32, 36, 44, 102, 104, 258.

1994 Sao hirsuta Barrande; Gozalo et al., pp. 44, 45, $48,50$.

1994 Sao aff. hirsuta Barrande. - Gozalo et al., pp. 48-50, pl. 1, figs 2-6, pl. 2.

1997 Sao hirsuta Barrande. - Chatterton \& Speyer, p. 174.

2000 Sao hirsuta Barrande. - Sdzuy, pp. 301, 305, 310, pl. 5, figs 7-12.

2004 Sao hirsuta Barrande. - Álvaro et al., p. 145.

2004 Sao hirsuta Barrande. - Fatka, p. 112.

2006 Sao hirsuta Barrande. - Kordule, pp. 290, 296-302.

2009 Sao hirsuta Barrande. - Fatka \& Mergl, p. 79.

Lectotype. - NM L12525, selected by Šnajdr (1958), from the Buchava Formation (Drumian), Skryje-Týřovice Basin, Czech Republic. Figured by Barrande (1852, pl. 7, fig. 15), Šnajdr (1958, pl. 44, fig. 10), Fig. 6D herein. This specimen was also designated lectotype of Ellipsocephalus nanus Barrande, 1846 by Marek (in Horný \& Bastl 1970, p. 212).

Diagnosis. - As for the genus.

Ontogeny. - The length-width dimensions of sixty protaspid specimens assigned to $S$. hirsuta were plotted (Fig. 3A). Three distinct protaspid stages (P1, P2 and P3) are recognized on the basis of size and morphological features. The protaspid stages are clearly distinguishable also in the frequency histogram (Fig. 3C). For postprotaspid development, six articulated early meraspides (degree 1) were plotted with the protaspides (Fig. 3B). This graph suggests the presence of two distinct stages within meraspid degree 1, with four (M1-4) and five (M1-5) segments
Table 2. Dimensions and trunk segment numbers of protaspid and early meraspid stages of Ptychopariida sp. A.

\begin{tabular}{|c|c|c|c|c|c|c|}
\hline Institution & Number & Stage & $\begin{array}{l}\text { Width } \\
(\mathrm{mm})\end{array}$ & $\begin{array}{c}\text { Length } \\
(\mathrm{mm})\end{array}$ & $\begin{array}{c}\text { Centroid } \\
\text { size }\end{array}$ & $\begin{array}{c}\text { Segment } \\
\text { number }\end{array}$ \\
\hline NM & L3688 & $\mathrm{P} 1$ & 0.62 & 0.56 & - & $?$ \\
\hline NM & L3699 & $\mathrm{P} 1$ & 0.64 & 0.54 & - & $?$ \\
\hline NM & L3700 & $\mathrm{P} 1$ & 0.76 & 0.61 & - & $?$ \\
\hline NM & L3703 & $\mathrm{P} 1$ & 0.62 & 0.52 & - & $?$ \\
\hline NM & L3706 & $\mathrm{P} 1$ & 0.68 & 0.61 & - & $?$ \\
\hline NM & L3717 & $\mathrm{P} 1$ & 0.64 & 0.6 & - & $?$ \\
\hline NM & L3722 & $\mathrm{P} 1$ & 0.62 & 0.54 & - & $?$ \\
\hline NM & L3729 & $\mathrm{P} 1$ & 0.66 & 0.51 & - & $?$ \\
\hline NM & L19008 & $\mathrm{P} 1$ & 0.66 & 0.51 & - & $?$ \\
\hline NM & L19009 & $\mathrm{P} 1$ & 0.62 & 0.5 & - & $?$ \\
\hline CGS & MS559 & $\mathrm{P} 1$ & 0.46 & 0.42 & - & $?$ \\
\hline CGS & MS11486 & $\mathrm{P} 1$ & 0.64 & 0.5 & - & $?$ \\
\hline CGS & 3155 & $\mathrm{P} 2$ & 0.7 & 0.67 & - & 2 \\
\hline CGS & 3217 & $\mathrm{P} 2$ & 0.68 & 0.68 & - & 2 \\
\hline CGS & 3507 & $\mathrm{P} 2$ & 0.64 & 0.62 & - & 2 \\
\hline CGS & 3522 & $\mathrm{P} 2$ & 0.64 & 0.61 & - & 2 \\
\hline NM & L3547 & $\mathrm{P} 2$ & 0.66 & 0.65 & - & 2 \\
\hline NM & L3551 & $\mathrm{P} 2$ & 0.7 & 0.69 & - & 2 \\
\hline NM & L3563 & $\mathrm{P} 2$ & 0.68 & 0.66 & - & 2 \\
\hline NM & L19010 & $\mathrm{P} 2$ & 0.76 & 0.67 & - & 2 \\
\hline CGS & MS561 & $\mathrm{P} 2$ & 0.7 & 0.65 & - & 2 \\
\hline CGS & MS562 & $\mathrm{P} 2$ & 0.64 & 0.63 & - & 2 \\
\hline CGS & 3280 & P3 & 0.66 & 0.75 & - & 3 \\
\hline NM & L3540 & P3 & 0.74 & 0.76 & - & 3 \\
\hline NM & L3549 & P3 & 0.76 & 0.82 & - & 3 \\
\hline NM & L3726 & P3 & 0.84 & 0.83 & - & 3 \\
\hline NM & L19011 & P3 & 0.9 & 0.85 & - & 3 \\
\hline NM & L19013 & P3 & 0.86 & 0.84 & - & 3 \\
\hline CGS & MS565 & P3 & 0.74 & 0.77 & - & 3 \\
\hline CGS & MS572 & P3 & 0.84 & 0.9 & - & 3 \\
\hline CGS & MS11476a & P3 & 0.84 & 0.78 & - & 3 \\
\hline
\end{tabular}

respectively in the meraspid pygidium. We found no individuals that could be assigned to meraspid degree 0 .

Protaspid stage 1 (Figs 4A, B, 8A): Exoskeleton circular in outline, $0.61-0.71 \mathrm{~mm}$ long and $0.66-0.78 \mathrm{~mm}$

Figure 4. Sao hirsuta Barrande, 1846. Buchava Formation, Skryje-Týřovice Basin. • A - protaspid stage 1; CGS 3229. • B - NM L3704, protaspid stage 1 with exposed hypostome (h). • C - CGS MŠ564, protaspid stage 2 with fixigenal and marginal spines on the trunk (arrows). $\bullet$ D - CGS MŠ563, protaspid stage 2 with fixigenal and marginal spines on the trunk (arrows). E, F - NM L19012, protaspid stage 2; E - general view showing hypostome (h) and librigena (lb); F - detail of hypostome with rostral plate (rp) and marginal spines (arrows). • G - NM L3727, protaspid stage 3. • H - CGS MŠ572, protaspid stage 3. • I - CGS MŠ568, protaspid stage 3. • J-L - CGS MŠ569, protaspid stage 3 with displaced librigena and hypostome; J - detail of doublure with spines; K - general view of specimen with librigena (lb) and hypostome (h); L - detail of hypostome with marginal spines (arrows) of protaspid stage 3 . Scale bars represent $0.2 \mathrm{~mm}$ in A-E, G-I, K; $0.1 \mathrm{~mm}$ in F, J, L. 

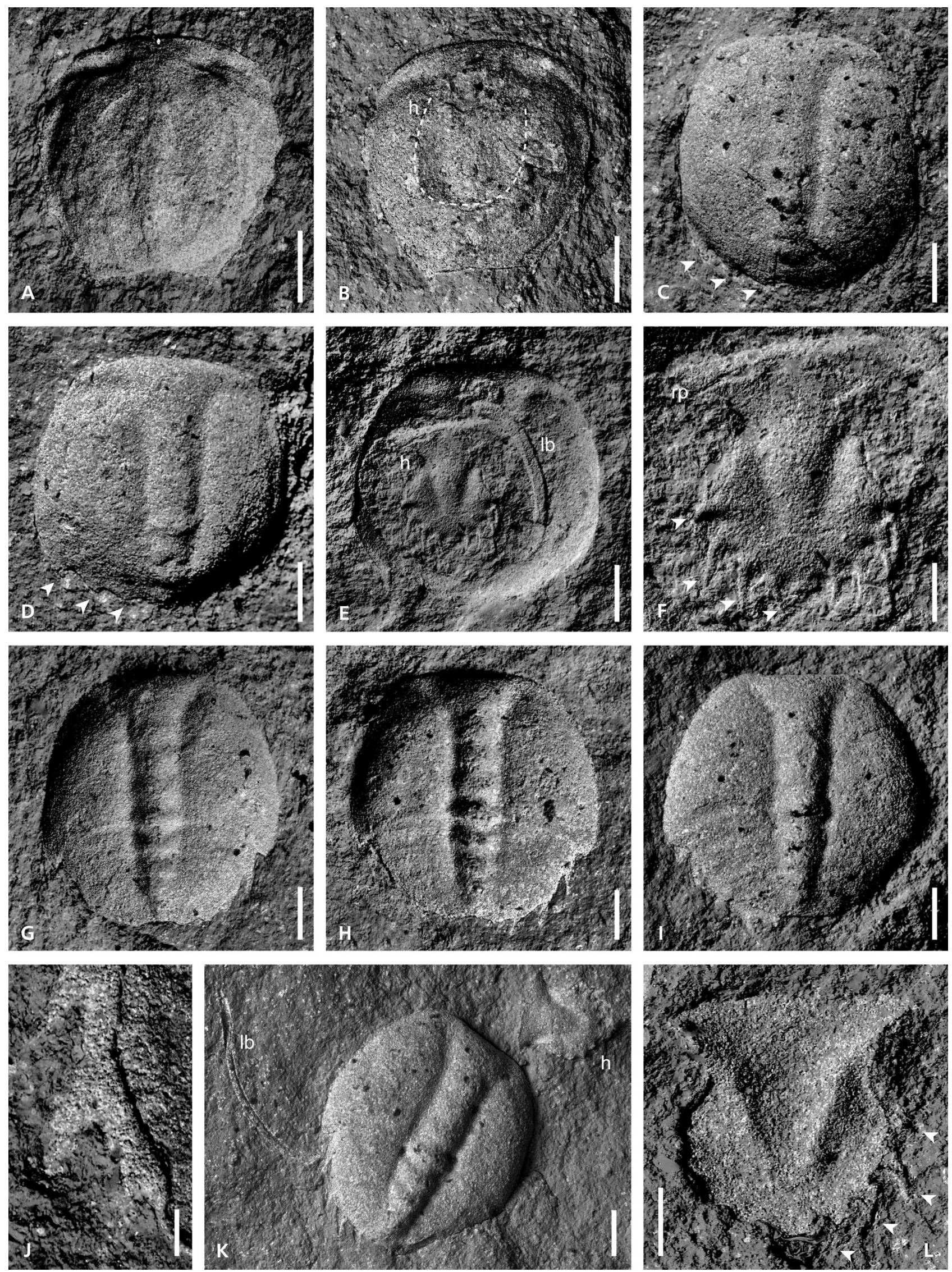
Table 3. Dimensions and trunk segment numbers of protaspid and early meraspid stages of Ptychopariida sp. B.

\begin{tabular}{llccccc}
\hline Institution Number & Stage & $\begin{array}{c}\text { Width } \\
(\mathrm{mm})\end{array}$ & $\begin{array}{c}\text { Length } \\
(\mathrm{mm})\end{array}$ & $\begin{array}{c}\text { Centroid } \\
\text { size }\end{array}$ & $\begin{array}{c}\text { Segment } \\
\text { number }\end{array}$ \\
\hline CGS & 3475 & $\mathrm{P}$ & 0.88 & 0.78 & - & $?$ \\
CGS & MS9646 & P & 0.96 & 0.99 & - & $?$ \\
CGS & MS9647 & P & 0.96 & 1.05 & - & $?$ \\
NM & L11427 & P & 1.05 & 1 & - & $?$ \\
\hline
\end{tabular}

wide, gently vaulted; axial furrows weakly developed; anterior fossulae large; eye ridges slender; posterior exoskeletal margin slightly concave in dorsal view. Three pairs of short fixigenal spines present: anterior fixigenal spine situated in anterior third (exsag.) of exoskeletal length, pointed laterally; mid-fixigenal spine occurring at posterior third (exsag.) of exoskeletal length, pointed postero-laterally; posterior fixigenal spine projecting from the posterior end of the exoskeleton (exsag.), pointed posteriorly. Ventral surface of the exoskeleton poorly known; hypostome reaching $\mathrm{ca}$ two-thirds of exoskeletal length (sag.).

Protaspid stage 2 (Figs 4C-F, 8B): Exoskeleton $0.72-0.86 \mathrm{~mm}$ long and $0.76-0.92 \mathrm{~mm}$ wide, moderately vaulted; axial part widening anteriorly; S1-S3 weakly defined, SO distinct; fossulae placed laterally from LA; facial suture marginal; LO approximately in posterior third of exoskeleton; posterior fixigenal spine located opposite two-thirds of exoskeletal length (sag.), oriented posteriorly. Hypostome conterminant, central lobe parabolic, posterior lobe circular with nine horizontally directed marginal spines. Trunk broadly rhombic (tr.) with two pairs of posterior spines; axis consisting of three segments; pleural parts smooth. Doublure narrow.

Protaspid stage 3 (Figs 4G-L, 5A-C, 8C): Exoskeleton circular to subhexagonal in outline, 0.91-1.09 mm long and 0.9-1.1 mm wide; LA expanding (tr.) forward, reaching (sag.) anterior border of cranidium; fossulae minute; eye ridges narrow; facial suture opisthoparian running mostly marginally; posterior cranidial border furrow weakly developed; LO slightly wider than L1; posterior cephalic marginal furrow located at exoskeletal midlength, running transversally from LO and distally slightly curved backward. Hypostome similar as in P2. Trunk semicircular to subtrapezoidal with four pairs of marginal spines; axis narrowing posteriorly, consisting of four segments; pleural furrows weakly developed. Doublure narrow with fine terrace ridges on librigena.

Postprotaspid development (Figs 5D-L, 6, 8D-F): The smallest cranidium is subtrapezoidal in outline, $0.66 \mathrm{~mm}$ long and $1.08 \mathrm{~mm}$ wide; later cranidia are proportionally wider. Throughout ontogeny the cephalon displays the following changes: glabella becomes relatively shorter; LA widens anteriorly until meraspid degree 6, narrows in the following degrees (7-8) so all glabellar lobes are approximately of the same width (tr.); in late meraspides and holaspides the glabella is forwardly tapering; lateral glabellar furrows become deeper and transverse; sagittal glabellar furrow appears in late meraspides; LO becomes proportionally wider; anterior border first appears as small projections anterolaterally from LA in meraspid degree 2; in subsequent stages the whole border increases in length (sag.) and the preglabellar furrow becomes distinct; in late ontogeny, preglabellar furrow deepens and forms a concave preglabellar field; palpebral lobes move backward slightly in early ontogeny and subsequently rapidly become arched laterally; anterior branch of facial suture extends, posterior branch curves inwards; in meraspid degree 2 distinct node appears close to proximal part of posterior cranidial border furrow and remains up to holaspid stages; tubercles appear in late ontogeny, firstly on glabella and genae and afterwards on whole cephalic border; narrow early meraspid librigenae become broad; genal spines proportionally shorten; cephalon becomes strongly vaulted and its anterior border convex in frontal view.

The hypostome undergoes the following changes during ontogeny: early meraspid hypostome is conterminant, bears marginal spines which subsequently disappear; later meraspid and holaspid hypostomes lack marginal spines; the separation of hypostome from rostral plate probably appears during the middle meraspid period; in later ontogeny the anterior hypostomal wings slightly extend transversely.

Thoracic segments of early meraspid stages show moderately vaulted axial part; pleural parts are almost flat, with small distal pleural spine; pleural furrows are distinct; in later stages the pleural parts become more vaulted; the pleural spines shorten in the late meraspides and they are truncated in holaspid period; the number of segments increases from one to seventeen.

Figure 5. Sao hirsuta Barrande, 1846. Buchava Formation, Skryje-Týřovice Basin. • A - NM L3732, protaspid stage 3. B C C CGS MŠ567, protaspid stage 3; B - showing librigena (lb); C - detail of librigenal doublure with fine terrace ridges (arrows). D - CGS MŠ573, meraspid degree 1-4. $\bullet$ E - CGS MŠ574, meraspid degree 1-5. $\bullet$ F - CGS 350, hypostome probably of meraspid degree 1 with rostral plate (rp) and marginal spines (arrows). $\bullet$ G - CGS MŠ578, meraspid degree 2. • H - CGS MŠ581, meraspid degree 4. • I - MBHR 89976, meraspid degree 4. • J, K - CGS MŠ588, middle meraspid stage; $\mathrm{J}$ - general view; $\mathrm{K}$ - detail of distal parts of thoracic pleurae showing doublure. $\bullet \mathrm{L}-\mathrm{CGS}$ MŠ 600 , hypostome of middle meraspid stage. Scale bars represent $0.2 \mathrm{~mm}$ in A-F, K, L; $0.5 \mathrm{~mm}$ in G-J. 

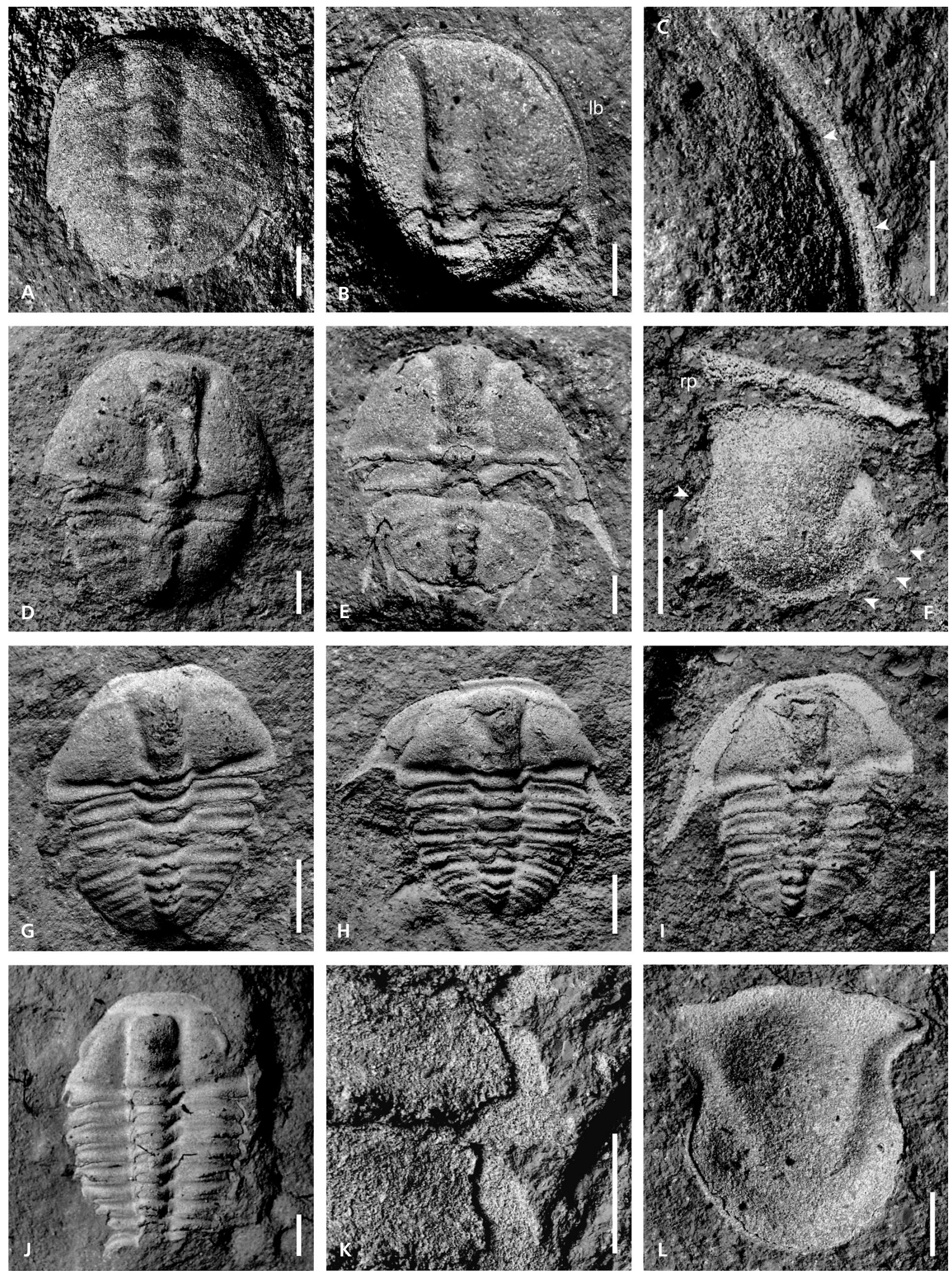
The pygidium shape changes from semicircular in early meraspides to broadly subhexagonal (tr.) in holaspides; the number of segments is four in meraspid degree 1 and subsequently increases to five. In early meraspid ontogeny, five pygidial segments generally remain, while the number of segments is usually four in second the half of meraspid ontogeny; starting with meraspid degree 15 , the number of segments in meraspid pygidium gradually decreases to one segment plus a terminal piece in holaspid pygidium.

Remarks on ontogeny. - The protaspid period of S. hirsuta is composed of three morphologically distinct stages (Fig. 3A). A similar three-stage protaspid period has been described in other species within the suborder Ptychopariina, such as in the menomoniid Bolaspidella housensis (Walcott, 1886) and Alataspis sesongensis Park \& Choi, 2011 (see Lee \& Chatterton 2005, fig. 4; Park \& Choi 2011, fig. 8A). The ptychopariid Spencella? sp. also shows three comparable protaspid stages (Chatterton \& Speyer 1997, fig. 170/1-9). However, some other trilobites such as calymenids (Chatterton et al. 1990) and proetids (Chatterton 1994) also have a three-stage protaspid period, so this character is not distinctive for Ptychopariina.

Šnajdr (1958) illustrated several specimens of S. hirsuta that he regarded as belonging to meraspid degree 0 . We reinterpret them as protaspid stage 3 , since the presence of an articulation between the protocranidium and the trunk could not be demonstrated in any of them, even when using SEM ( $c f$. Figs 4G-I, K, 5A, B). Accordingly, we hypothesize that the ontogeny of $S$. hirsuta did not include a meraspid degree 0 (Fig. 3B). This is a unique feature, although in some other trilobites with well-known ontogeny, the meraspid degree 0 still remains undiscovered. It could not be excluded that this feature was not so exceptional (for instance the ontogeny of Triarthrus eatoni in Hughes et al. 2006). However, it has been shown that more than one articulation apparently became operational in between two instars in some trilobites, resulting in the release of two segments in the thorax (e.g. Chatterton 1971). If something similar happened at the protaspis/meraspis transition in $S$. hirsuta, this could explain the absence of meraspid degree 0 specimens in our sample. This hypothesis is supported by the AGI, AGR, IDC and Dyar's index values (Table 4), which are comparable with those observed in other trilobites (e.g. Chatterton et al. 1990, Hunt \& Chapman 2001, Fusco et al. 2011). Moreover, the Dyar's index values are similar between successive instars, from P1 to M1-5, suggesting that no growth stages are missing. The ontogeny of $S$. hirsuta is also remarkable in having two meraspid degree 1 stages, having four and five segments respectively in the meraspid pygidium. Comparable multiple-stage meraspid degrees are known in other trilobites (Hughes et al. 2006).

\section{Genus uncertain}

\section{Ptychopariida sp. A}

Figures 7A-K, 8H-J

Remarks. - Protaspides of this species were assigned to S. hirsuta by Barrande (1852, pl. 7, fig. 1d, e), Růžička (1943, pl. 4, figs 7-10, 12, pl. 5, fig. 5), Whittington (1957, pl. 116, figs $14,15,18)$ and Šnajdr $(1958$, pl. 43, figs $1-6$, 10-12). However, the specimens differ from protaspides of S. hirsuta in having larger palpebral lobes, and in the morphology of the trunk including the absence of marginal spines. In addition, the individual protaspid stages of Ptychopariida sp. A are comparatively smaller than the corresponding stages of $S$. hirsuta; stages 1 and 2 of $S$. hirsuta are approximately the same size as stages 2 and 3 respectively of Ptychopariida sp. A. Several early meraspides assigned to S. hirsuta by previous authors (Růžička 1943, pl. 4, fig. 16; Whittington 1957, pl. 116, figs 20, 21; Šnajdr 1958, pl. 43, figs 24,34 ) may also belong to Ptychopariida sp. A, as suggested by their large palpebral lobes and their modest pleural spines.

Ontogeny. - Three protaspid stages can be recognized on the basis of exoskeletal morphology, but compared with $S$. hirsuta they are not as clearly differentiated by size (Fig. 3D).

Protaspid stage 1 (Figs 7 B, C, 8H): Exoskeleton circular in outline, $0.5-0.61 \mathrm{~mm}$ long and $0.62-0.76 \mathrm{~mm}$ wide, slightly vaulted; axial part widening anteriorly, delimited by well-developed furrows; fossulae large; distinct palpebral lobes reaching exoskeletal mid-length (exsag.), posterior margin concave in dorsal view. Anterior fixigenal spine located behind the palpebal lobe; mid-fixigenal spine situated in posterior quarter of the exoskeleton; posterior fixigenal spine relatively long and located at the posterior end of exoskeleton (exsag.).

Protaspid stage 2 (Figs 7D, E, 8I): Exoskeleton circular in outline, $0.61-0.69 \mathrm{~mm}$ in length and $0.64-0.76 \mathrm{~mm}$ in width, moderately vaulted; glabella widening anteriorly in anterior quarter; short pair of posterior fixigenal spines present; LO in posterior third of exoskeleton; posterior cephalic marginal furrow weakly defined, running transversally from LO and then suddenly curving backward. Trunk bearing two axial rings; pleural parts effaced.

Protaspid stage 3 (Figs 7F-H, 8J) : Exoskeleton circular to subtetragonal in outline, $0.75-0.9 \mathrm{~mm}$ long and 0.66-0.86 mm wide; anterior part of glabella widening anteriorly; palpebral lobes large; facial suture opisthoparian; librigena narrow, curved, with fine terrace ridges on the doublure; LO approximately in posterior third of exoskeleton; posterior 

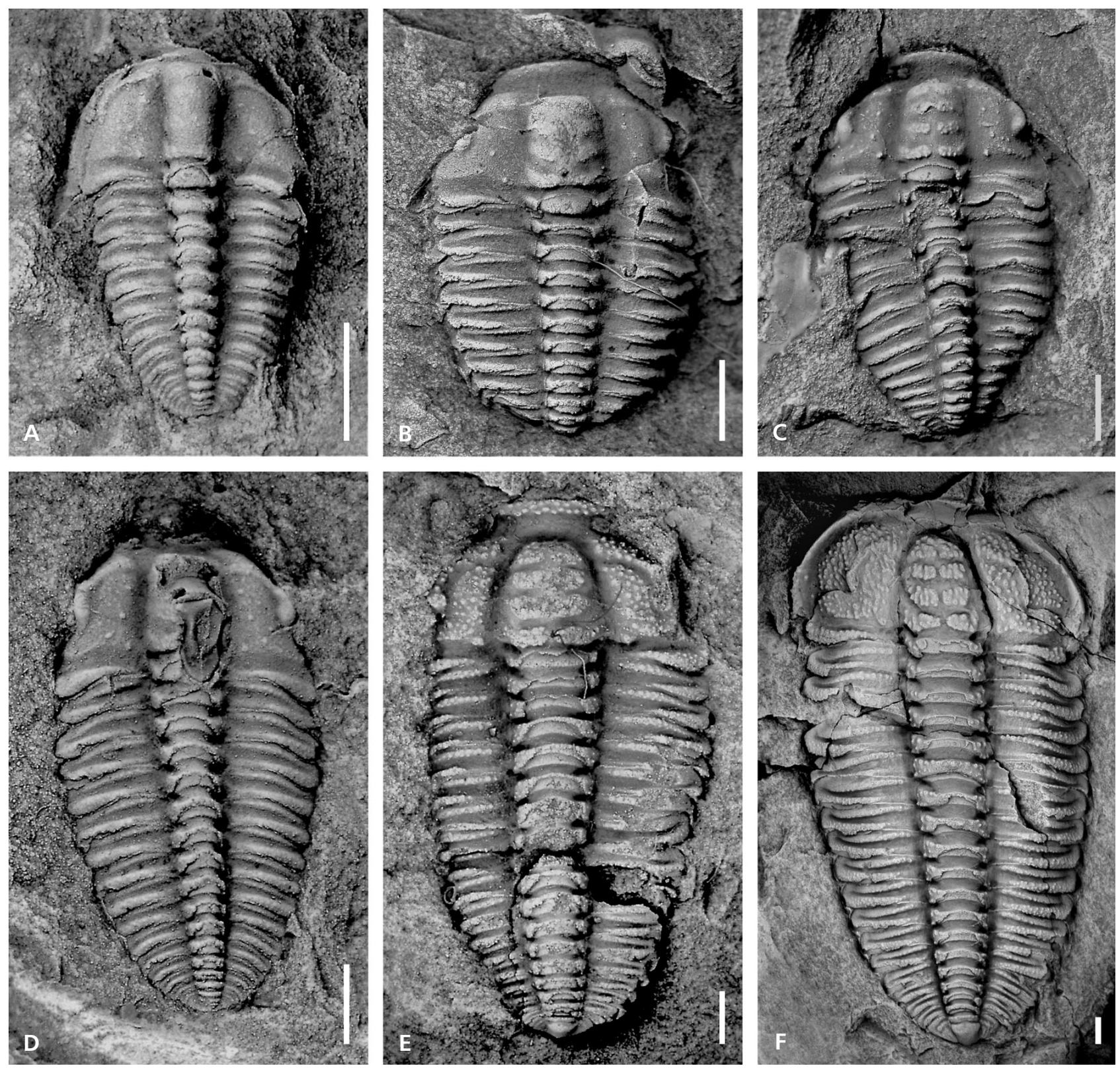

Figure 6. Sao hirsuta Barrande, 1846. Buchava Formation, Skryje-Týřovice Basin. • A - NM L12517, meraspid degree 8. B - NM L12521, late meraspid stage. $・$ C - NM L12524, meraspid degree 14. D - NM L12525, lectotype, meraspid degree 14. $・$ E - NM L12530, early holaspid stage. - F - NM L12537, late holaspid stage. Scale bars represent $1 \mathrm{~mm}$.

cephalic marginal furrow distinct, deflected posteriorly. Trunk with three segments; posterior margin without spines.

Meraspid degrees 0-2 (Figs 7I-K): Cranidia of degrees $0-2$ subrectangular in outline, $0.6-1.0 \mathrm{~mm}$ long and $1.2-1.51 \mathrm{~mm}$ wide; glabella slightly widening anteriorly; glabellar furrows moderately impressed; short (sag.) anterior border developed; palpebral lobes large, reaching backwards to approximately level with glabellar midlength (sag.); posterior cranidial border furrows slightly widening distally; free cheeks narrow with short posteriorly oriented genal spine; doublure narrow. Thorax moderately vaulted (tr.); pleurae ending distally in small spines; number of thoracic segments increasing from zero to two. Meraspid pygidium semicircular; axis composed of six segments; pleural furrows weak; pleural spines modest.

Remarks on ontogeny. - One very small protaspis, indicated by a question mark in Fig. 3D, may represent an additional stage. It is rather similar in morphology to specimens that we have assigned to protaspid stage 1 except that the posterior fixigenal spines are slightly longer (Fig. 7A). 
Table 4. Average values of length $(L)$, width $(W)$ and centroid size $(C S)$, and the results of growth formulas (see Material and methods for detailed information) of protaspid and early meraspid stages of Sao hirsuta Barrande, 1846.

\begin{tabular}{lcccccccc}
\hline Stage & $L(\mathrm{~mm})$ & $W(\mathrm{~mm})$ & $C S$ & $D i(\mathrm{l})$ & $D i(\mathrm{w})$ & $D i(\mathrm{cs})$ & $I D C(\mathrm{l})$ & $I D C(\mathrm{w})$ \\
\hline P1 & 0.66 & 0.72 & 0.55 & - & - & - & - & - \\
P2 & 0.80 & 0.83 & 0.66 & 1.21 & 1.16 & 1.20 & 0.97 & 0.99 \\
P3 & 0.98 & 0.99 & 0.80 & 1.22 & 1.19 & 1.20 & 0.92 & 0.88 \\
M1-4 & 1.17 & 1.12 & - & 1.19 & 1.13 & - & 0.91 & 0.90 \\
M1-5 & 1.33 & 1.23 & - & 1.14 & 1.10 & - & - & - \\
\hline & AGI (1) & 0.08 & AGI (w) & 0.06 & AGR (l) & 1.19 & AGR (w) & 1.14 \\
\hline
\end{tabular}

Some small protaspides illustrated by Růžička (1943, pl. 4, figs 7, 8, pl. 5, fig. 5) as S. hirsuta were considered by Whittington (1957, p. 940) possibly to belong to the taxon we designate Ptychopariida sp. B. However, we consider it more likely that they belong to the protaspid stage 1 of Ptychopariida sp. A, because they share a large palpebral lobe with stages 2 and 3 of that taxon. Moreover, stage 1 protaspides of Ptychopariida sp. A are more common in the Buchava Formation than protaspides of Ptychopariida sp. B, as also observed by Šnajdr (1958).

These early ontogenetic stages cannot be assigned with confidence to any of the other trilobite taxa that occur with S. hirsuta in the Paradoxides (Eccaparadoxides) pusillus Zone in the Skryje-Týřovice Basin. However, considering their comparatively high abundance and their characteristically distinct palpebral lobes, they probably belong to one of the normal-eyed taxa common at the Týrovice - Pod hruškou locality (e.g. Agraulos, Skreiaspis; cf. Fatka 2004, table 1).

\section{Ptychopariida sp. B}

Figures 7L, 8G

Remarks. - This protaspid stage of uncertain affinity was briefly described and illustrated by Růžička (1943, textfigs on pp. 14, 31) as his so-called "Barrande's larva". Šnajdr (1958) listed additional material but did not provide any new observations.

Ontogeny. - Protaspides of Ptychopariida sp. B are represented by only four specimens, all of similar shape and size (Fig. 3E).

Protaspid stage (Figs 7L, 8G): Protaspides circular in outline, $0.78-1.05 \mathrm{~mm}$ long and $0.88-1.06 \mathrm{~mm}$ wide, moderately vaulted; axis weakly defined; fossulae large; eye ridge narrow; posterior exoskeletal margin moderately convex. Diminutive anterior fixigenal spine located opposite exoskeletal mid-length; short mid-fixigenal spine opposite posterior quarter (sag.) of exoskeleton; slightly larger postero-ventrally oriented fixigenal spine projecting from the posterior end of exoskeleton.

Remarks on ontogeny. - The exact affinities of these protaspides are uncertain. Only members of the Order Ptychopariida or the Superfamily Paradoxidoidea are known from the Skryje-Týřovice Basin. We assign the present specimens to the Ptychopariida because protaspides of the Paradoxidoidea are quite different in morphology ( $c f$. Šnajdr 1958, figs 20, 23; Chatterton \& Speyer 1997, fig. 168).

\section{Mode of life of protaspides and possible implication for palaeobiogeography}

Several workers have focused on trilobite life history strategies during ontogeny (Speyer \& Chatterton 1989; Chatterton \& Speyer 1989, 1997; Chatterton et al. 1990; Lerosey-Aubril 2006; Crônier 2007, etc.). Speyer \& Chatterton (1989) established a dichotomy in the protaspid body plan - the adult-like and nonadult-like plans. Adultlike protaspides are usually disk-shaped, with a more or less planar ventral surface, a comparatively small hypostome, and an inturned doublure commonly bearing terrace ridges. Nonadult-like protaspides are globular, with an enrolled doublure and a hypostome commonly with long spines directed obliquely downwards. Based on these features, Speyer \& Chatterton (1989) suggested a benthic life style for the adult-like protaspides and a planktic life style for the nonadult-like protaspides.

Figure 7. All specimens from Buchava Formation, Skryje-Týřovice Basin. • A-K - Ptychopariida sp. A. • A - CGS MŠ559, smallest specimen showing fixigenal spines (arrows). • B - CGS MŠ560, protaspid stage 1. • C - NM L19008, protaspid stage 1 with fixigenal spines (arrows). D - CGS MŠ561, protaspid stage 2. • E - CGS MŠ562, protaspid stage 2.・F - CGS MŠ565, protaspid stage 3. • G - CGS MŠ572, protaspid stage 3. • H - NM L3549, librigenal doublure with fine terrace ridges (arrows) of protaspid stage 3. • I - CGS MŠ577, meraspid degree 0 with librigena (lb). • J - CGS MŠ576, meraspid degree 1. $\bullet$ K - CGS MŠ577, meraspid degree 2. $\bullet$ L - Ptychopariida sp. B, CGS MŠ9647, protaspid stage showing fixigenal spines (arrows). Scale bars represent $0.2 \mathrm{~mm}$ in $\mathrm{A}-\mathrm{H}, \mathrm{L} ; 0.5 \mathrm{~mm}$ in $\mathrm{I}-\mathrm{K}$. 

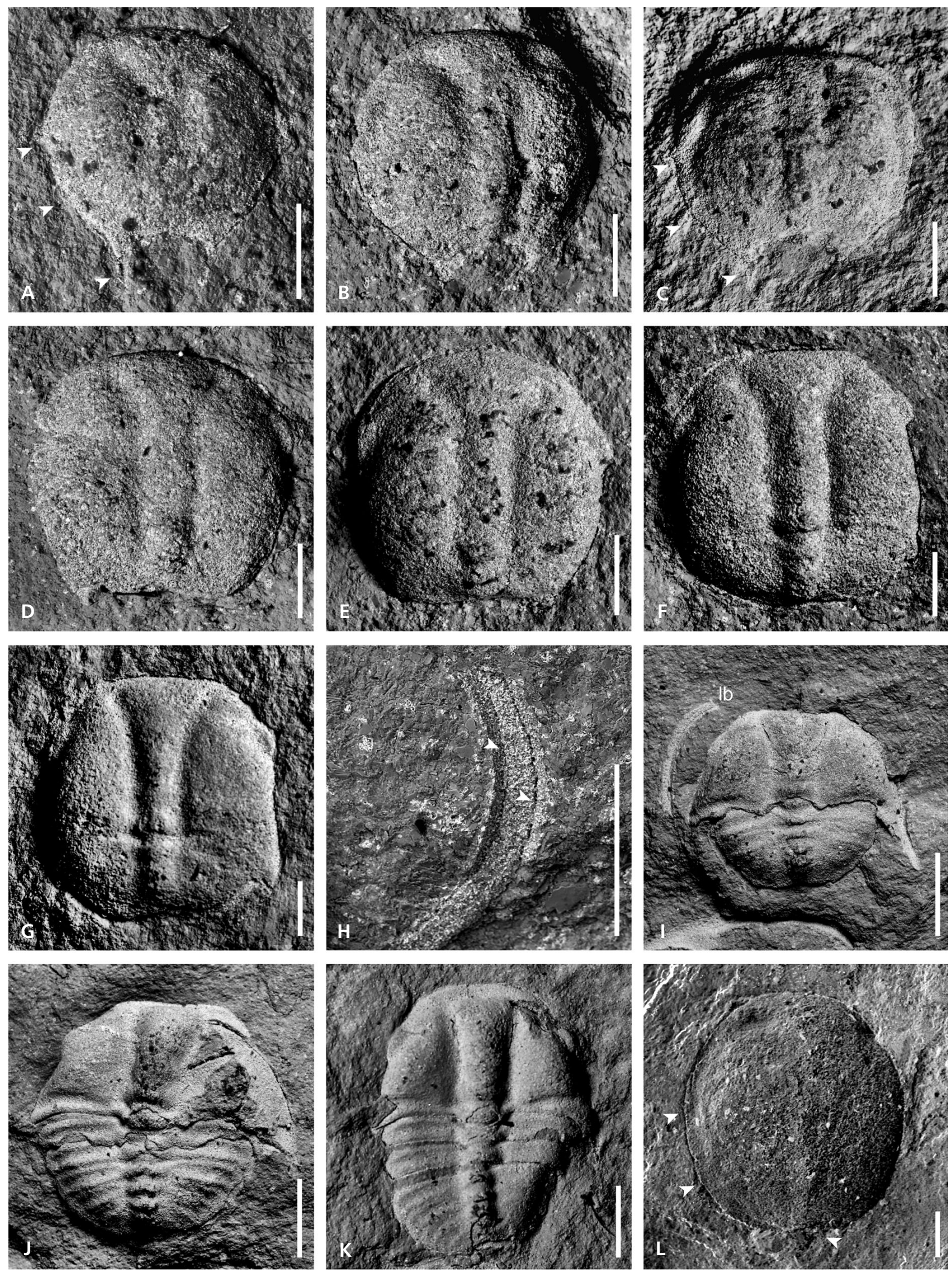


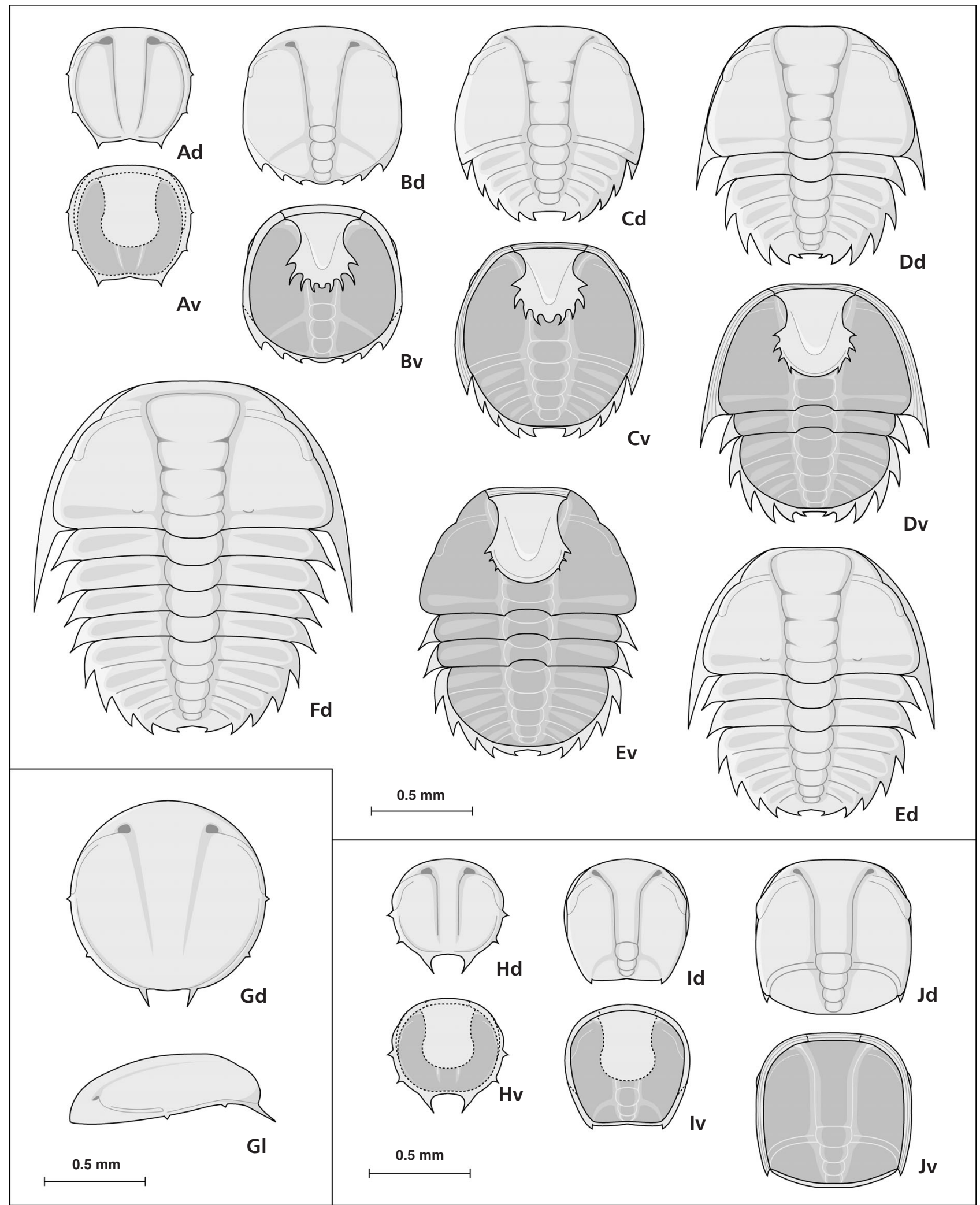

Figure 8. Reconstruction of the exoskeleton of early ontogenetic stages of Sao hirsuta Barrande, 1846 (A-F), Ptychopariida sp. B (G) and Ptychopariida sp. A (H-J), in dorsal (d), ventral (v) or lateral (1) views. • A - protaspid stage 1. • B - protaspid stage 2. • C - protaspid stage 3. $\bullet \mathrm{D}$ - meraspid degree $1-5$. $\bullet \mathrm{E}-$ meraspid degree $2-5 . \bullet \mathrm{F}-$ meraspid degree $4-5$. $\bullet \mathrm{G}$ - protaspid stage. $\bullet \mathrm{H}-$ protaspid stage 1 . $\bullet \mathrm{I}-$ protaspid stage 2 . $\cdot \mathrm{J}$ - protaspid stage 3 . Inferred features are shown by stippled line. 
Protaspid stages 2 and 3 of S. hirsuta and Ptychopariida sp. A have an adult-like morphology. They share the dorso-ventrally flattened exoskeleton, a comparatively small hypostome with horizontally oriented spines, a planar ventral surface and an inturned doublure. Moreover, protaspid stage 3 of both S. hirsuta and Ptychopariida sp. A bear fine terrace ridges on the ventral doublure surface (Figs 5C, 7H). All these characters suggest that these protaspid stages were probably benthic. In the protaspid stage 1 of both $S$. hirsuta and Ptychopariida sp. A the doublure between the posterior spines seems to be inturned and, despite diagenetic flattening, it is also obvious that the exoskeleton was very slightly arched and had a planar ventral surface. Chatterton \& Speyer (1997) considered that protaspides of this shape were benthic rather than planktic, although several earlier workers supposed that they had a planktic lifestyle. We therefore consider that $S$. hirsuta and Ptychopariida sp. A had a life-history strategy corresponding to type IIIa of Chatterton \& Speyer (1997), characterized by an entirely benthic protaspid period. This could explain why the palaeogeographic distribution of S. hirsuta is restricted to the western margin of Gondwana. Other members of the Solenopleuropsinae are also restricted to West Gondwana (Álvaro \& Vizcaïno 1997), possibly due to the similarly limited dispersal capabilities of their larval stages.

Protaspides of Ptychopariida sp. B have morphology typical of a comparatively early protaspid stage (three pairs of fixigenal spines, trunk portion not distinguishable) but are very large for such an early stage (Fig. 3E). There are two possible explanations for their large size, as proposed also by Lerosey-Aubril (2006) for proetoid protaspides: (1) a taphonomic explanation - there were smaller protaspid stages but they were uncalcified and/or they are not preserved; or (2) a lecitotrophic explanation - lecitotrophic larvae are usually much larger than planktotrophic ones (e.g. Thorson 1950), so the protaspides of Ptychopariida sp. B may have been nourished with a large yolk. The lecitotrophic explanation seems more probable because of the early protaspid morphology of the specimens.

\section{Conclusions}

The detailed and quantitative description of the early ontogeny of Sao hirsuta, Ptychopariida sp. A and Ptychopariida sp. B allows the following conclusions to be drawn:

1. S. hirsuta had three protaspid instars. The adult-like morphology of the protaspides indicates they had a benthic mode of life, explaining the very restricted palaeogeographic distribution of the species.

2. The apparent absence of the meraspid degree 0 in S. hirsuta is unique in trilobite ontogeny. Instead of the meraspid degree 0 there are two stages in degree 1 , with four and five segments respectively in the meraspid pygidium.

3. Ptychopariida sp. A, previously considered part of the ontogenetic sequence of $S$. hirsuta, is classified as a separate taxon. It has at least three protaspid stages characterized by large palpebral lobes.

4. The protaspis of Ptychopariida sp. B has the morphology of an early protaspid stage but is of unusually large size, suggesting that the larvae may have been lecitotrophic.

\section{Acknowledgements}

We thank David Holloway, Nigel Hughes and Rudy LeroseyAubril whose insightful comments and language corrections greatly improved this contribution. Martina Korandová, Petr Kraft, Martin Valent and Vojtěch Turek kindly made the studied material available. Martin Mazuch and Boris Ekrt were helpful with SEM photography. The research is supported by GA UK (Grant Agency of Charles University) No. 656912: Ontogeny of selected taxa of trilobites and agnostids from the Middle Cambrian of the Barrandian area, Contact Mobility-Barrande Program (Project No. MEB 021122 - PHC Barrande 24465SH), Prvouk P44 and Czech Geological Survey Project 334600.

\section{References}

Álvaro, J.J. \& Vizcaïno, D. 1997. Revision des trilobites Solenopleuropsinae du Cambrien moyen de la Montagne Noire (France). Geobios 30(4), 541-561.

DOI 10.1016/S0016-6995(97)80121-0

Álvaro, J.J., Vizcaïno, D., Kordule, V., Fatka, O. \& Pillola, J.L. 2004. Some solenopleurine trilobites from the Languedocian (late mid Cambrian) of Western Europe. Geobios 37(2), 135-147. DOI 10.1016/j.geobios.2003.03.009

Angelin, N.P. 1854. Palaeontologica Scandinavica. Pars I: Crustacea formationis transitionis. Fasc. 2. i-ix, 21-92, pls 25-41. Academiae Regiae Scientiarum Suecanae, Holmiae.

BARRANDE, J. 1846. Notice préliminaire sur le Systême silurien et les Trilobites de Bohême. 97 pp. Hirschfeld, Leipzig.

BarRande, J. 1852. Systême silurien du centre de la Bohême. Ière partie: Recherches paléontologiques. Vol. 1. Crustacés: trilobites. 935 pp. Published by the author, Prague \& Paris.

BEECHER, C.E. 1895. The larval stages of trilobites. The American Geologist 16, 166-197.

Billberg, G.J. 1820. Enumeratio insectorum in Museo. 138 pp. Typis Gadelianis, Stockholm. DOI 10.5962/bhl.title.49763

BoоKsteIn, F.L. 1991. Morphometric tools for landmark data/geometry and biology. 435 pp. Cambridge University Press, Cambridge.

Chatterton, B.D.E. 1971. Taxonomy and ontogeny of SiluroDevonian trilobites from near Yass, New South Wales. Palaeontographica, Abteilung A 137(1-3), 1-108.

Chatterton, B.D.E. 1994. Ordovician proetide trilobite Dimero- 
pyge, with a new species from northwestern Canada. Journal of Paleontology 68(3), 541-556.

Chatterton, B.D.E. \& Speyer, S.E. 1989. Larval ecology, life history strategies, and patterns of extinction and survivorship among Ordovician trilobites. Paleobiology 15(2), $118-132$.

Chatterton, B.D.E. \& Speyer, S.E. 1997. Ontogeny, 173-247. In KAESLER, R.L. (ed.) Treatise on Invertebrate Paleontology. Part O, Arthropoda 1, Trilobita 1, revised. Volume 1. Geological Society of America \& University of Kansas Press, Lawrence.

Chatterton, B.D.E., Siveter, D.J., Edgecombe, G.D. \& Hunt, A.S. 1990. Larvae and relationships of the Calymenina (Trilobita). Journal of Paleontology 64(2), 255-277.

CrôNIER, C. 2007. Larval morphology and ontogeny of an Upper Devonian phacopid: Nephranops from Thuringia, Germany. Journal of Paleontology 81(4), 684-700. DOI 10.1666/pleo 0022-3360(2007)081[0684:LMAOOA]2.0.CO;2

Drost, K., Linnemann, U., McNaughton, N., Fatka, O., Kraft, P., Gemlich, M., Tonk, C. \& MareK, J. 2004. New data on the Neoproterozoic-Cambrian geotectonic setting of the TepláBarrandian volcano-sedimentary successions: geochemistry, $\mathrm{U}-\mathrm{Pb}$ zircon ages, and provenance (Bohemian Massif, Czech Republic). International Journal of Earth Sciences (Geologische Rundschau) 93, 742-757. DOI 10.1007/s00531-004-0416-5

Dyar, G.H. 1890. The number of moults of lepidopterous larvae. Psyche 5, 420-422. DOI 10.1155/1890/23871

Edgecombe, G.D., Speyer, S.E. \& Chatterton, B.D.E. 1988. Protaspid larvae and phylogenetics of encrinurid trilobites. Journal of Paleontology 62(5), 779-799.

FatKA, O. 2004. Association of fossils and history of research at the Týřovice - „Pod hruškou“ locality (Middle Cambrian, Skryje-Týřovice Basin, Barrandian area). Journal of the Czech Geological Society 49(3-4), 107-117.

FAtKa, O., KRAFt, P. \& Szabad, M. 2011a. Wiwaxia Walcott in Middle Cambrian of the Barrandian area (Czech Republic). Acta Palaeontologica Polonica 56(4), 871-875. DOI 10.4202/app.2009.0052

FatKa, O. \& Mergl, M. 2009. The 'microcontinent' Perunica: status and story 15 years after conception, 65-101. In BASSETT, M.J. (ed.) Early Palaeozoic peri-Gondwana terranes: new insights from tectonics and biogeography. Geological Society of London Special Publication 325. DOI 10.1144/SP325.4

FATKa, O., Micka, V., SZAbad, M., VoKáč, V. \& Vorel, T. 2011b. Nomenclature of Cambrian lithostratigraphy of the Skryje-Týřovice Basin. Bulletin of Geosciences 86(4), 841-858. DOI 10.3140/bull.geosci.1284

FAtKa, O. \& SzABAD, M. 2011. Burrowing trilobite caught in the act. Paläontologische Zeitschrift 85(4), 465-470. DOI 10.1007/s12542-011-0102-4

Feist, R. \& Lerosey-AubriL, R. 2008. Assessing the hypothesis of a third tagma in scutelluid trilobites: arguments from ontogenetic, functional and evolutionary perspectives, 127-133. In Rábano, I., Gozalo, R. \& García-Bellido, D. (eds) Advances in trilobite research. Cuadernos del Museo Geominero, No. 9. Instituto Geológico y Minero de España, Madrid.

Fortey, R.A. 1990. Ontogeny, hypostome attachment and trilobite classification. Palaeontology 33(3), 529-576.
ForTEY, R.A. 2001. Trilobite systematics: the last 75 years. Journal of Paleontology 75(6), 1141-1151.

DOI 10.1666/0022-3360(2001)075<1141:TSTLY>2.0.CO;2

Fortey, R.A. \& Chatterton, B.D.E. 1988. Classification of the trilobite suborder Asaphida. Palaeontology 31(1), 165-222.

Fusco, G., Garland, T., Hunt, G. \& Hughes, N.C. 2011. Developmental trait evolution in trilobites. Evolution 66(2), 314-329. DOI 10.1111/j.1558-5646.2011.01447.x

Gozalo, R., Liñán, E. \& Álvaro, J. 1994. Trilobites de la Subfamilia Solenopleuropsinae Thoral, 1947 del Cámbrico Medio de la Unidad de Alconera (Zona de Ossa-Morena, SO de España). Boletin de la Real Sociedad Española de Historia Natural, Seccion Geologica 89(1-4), 43-54.

Hammer, Ø., Harper, D.A.T. \& Ryan, P.D. 2001. Past: paleontological statistics software package for education and data analysis. Palaeontologia Electronica 4(1), 1-9. [Available free of charge at .]

HAVLíčEK, V. 1971. Stratigraphy of the Cambrian of Central Bohemia. Sborník geologických věd, Geologie 20, 7-52.

Hawle, I. \& CoRdA, A.J.C. 1847. Prodrom einer Monographie der böhmischen Trilobiten. 176 pp. J.G. Calve, Prague. [Reprinted in 1848 in Abhandlungen der königlichen böhmischen Gesellschaft der Wissenschaften 5(5), 119-292.]

HoRnÝ, R. \& BASTL, F. 1970. Type specimens of fossils in the National Museum Prague. Volume 1. Trilobita. 354 pp. Národní muzeum, Praha.

Hughes, N.C. 2007. The evolution of trilobite body patterning. Annual Review of Earth and Planetary Sciences 35, 401-434. DOI 10.1146/annurev.earth.35.031306.140258

Hughes, N.C., Minelli, A. \& Fusco, G. 2006. The ontogeny of trilobite segmentation: a comparative approach. Paleobiology 32(4), 602-627. DOI 10.1666/06017.1

Hunt, G. \& Chapman, R.E. 2001. Evaluating hypotheses of instar-grouping in arthropods: a maximum likelihood approach. Paleobiology 27(3), 466-484. DOI 10.1666/0094-8373(2001)027<0466:EHOIGI>2.0.CO;2

Hupé, P. 1953. Classe des trilobites, 44-246. In Piveteau, J. (ed.) Traité de paléontologie, Vol. 3. Masson et Cie, Paris.

Kordule, V. 2006. Ptychopariid trilobites in the Middle Cambrian of Central Bohemia (taxonomy, biostratigraphy, synecology). Bulletin of Geosciences 81(4), 277-304.

DOI 10.3140/bull.geosci.2006.04.277

Lee, D.-C. \& Chatterton, B.D.E. 2005. Protaspid ontogeny of Bolaspidella housensis (Order Ptychopariida, Class Trilobita), and other similar Cambrian protaspides. Transactions of the Royal Society of Edinburgh, Earth Sciences 96(1), 21-41. DOI 10.1017/S026359330000122X

Lefebvre, B. \& FAtKA, O. 2003. Palaeogeographical and palaeoecological aspects of the Cambrian-Ordovician radiation of echinoderms in Gondwanan Africa and periGondwanan Europe. Palaeogeography, Palaeoclimatology, Palaeoecology 195(1), 73-97. DOI 10.1016/S0031-0182(03)00303-1

Lerosey-Aubril, R. 2006. Ontogeny of Drevermannia and the origin of blindness in Late Devonian proetoid trilobites. Geological Magazine 143(1), 89-104. DOI $10.1017 /$ S0016756805001421

Lerosey-Aubril, R. \& Feist, R. 2005. First Carboniferous protaspid larvae (Trilobita). Journal of Paleontology 79(4), 
$702-718$.

DOI 10.1666/0022-3360(2005)079[0702:FCPLT]2.0.CO;2

Maletz, J., Steiner, M. \& FatKa, O. 2005. Middle Cambrian pterobranchs and the question: What is a graptolite? Lethaia 38(1), 73-85. DOI 10.1080/00241160510013204

Mašek, J., Straka, J., Hrazdíra, P., PÁlenský, P., ŠtěPánek, P. \& HỦla, P. 1997. Geological and nature conservation map. Protected landscape area and biosphere reserve Křivoklátsko. Czech Geological Survey, Praha.

Mergl, M. \& Kordule, V. 2008. New Middle Cambrian lingulate brachiopods from the Skryje-Týrovice area (Central Bohemia, Czech Republic). Bulletin of Geosciences 83(1), 11-22. DOI 10.3140/bull.geosci.2008.01.011

PARK, T.-Y. \& ChOI, D.K. 2009. Post-embryonic development of the Furongian (late Cambrian) trilobite Tsinania canens: implications for life mode and phylogeny. Evolution \& Development 11(4), 441-455. DOI 10.1111/j.1525-142X.2009.00350.x

PARK, T.-Y. \& ChOI, D.K. 2011. Trilobite faunal successions across the base of the Furongian Series in the Taebaek Group, Taebaeksan Basin, Korea. Geobios 44(5), 481-498.

DOI 10.1016/j.geobios.2011.02.003

Poulsen, C. 1959. Family Solenopleuridae Angelin, 1854, 274-278. In Moore, R.C. (ed.) Treatise on Invertebrate Paleontology. Part O. Arthropoda 1. Geological Society of America \& University of Kansas Press, Lawrence.

RoHLF, F.J. 2006a. TpsDig2, digitize landmarks and outlines, version 2.10. Department of Ecology and Evolution, State University of New York at Stony Brook. [Available free of charge at http://life.bio.sunysb.edu/morph/.]

RoHLF, F.J. 2006b. TpsRelw, relative warp analysis, version 1.45 . Department of Ecology and Evolution, State University of New York at Stony Brook. [Available free of charge at http://life.bio.sunysb.edu/morph/.]

RƯŽIČKA, R. 1943. Př́ispěvek k ontogenii českých Paradoxidů a rodu Sao (Beitrag zur Ontogenie der böhmischen Paradoxiden und der Gattung Sao). Věstník Královské České společnosti nauk, Tř́ida matematicko-přirodovedecká 1943, 1-43.

SDZuY, K. 2000. Das Kambrium des Frankenwaldes: 3. Die Lip- pertsgrüner Schichten und ihre Fauna. Senckenbergiana lethaea 79(2), 301-327.

Speyer, S.E. \& Chatterton, B.D.E. 1989. Trilobite larvae and larval ecology. Historical Biology 3(1), 27-60.

DOI 10.1080/08912968909386512

SwinnerTon, H.H. 1915. Suggestions for a revised classification of the trilobites. Geological Magazine 6, 487-496, 538-545. DOI 10.1017/S0016756800203634

ŠNAJDR, M. 1958. Trilobiti českého středního kambria (Bohemian Middle Cambrian trilobites). Rozpravy Ústředního ústavu geologického 20, 1-280.

ŠNAJDR, M. 1990. Bohemian trilobites. 265 pp. Geological Survey, Prague.

THORAL, M. 1947. Trois nouveaux genres de trilobites acadiens du Languedoc et d'Espagne. Comptes Rendus des Séances de l'Académie des Sciences 244, 59-60.

Thorson, G. 1950. Reproductive and larval ecology of marine bottom invertebrates. Biological Reviews 25, 1-45. DOI 10.1111/j.1469-185X.1950.tb00585.x

VALIČEK, J. \& Š ARIČ, R. 2001. New finds Luhops expectans (Barrande, 1852) (Trilobita) from Barrandian Middle Cambrian (Bohemia). Palaeontologia Bohemiae 7, 54-61.

WalcotT, C.D. 1886. Second contribution to the studies of the Cambrian faunas of North America. United States Geological Survey Bulletin 30, 1-369.

Whittington, H.B. 1957. Ontogeny of Elliptocephala, Paradoxides, Sao, Blainia and Triarthrus (Trilobita). Journal of Paleontology 31(5), 934-946.

Whittington, H.B. 1959. Ontogeny of Trilobita, 127-145. In Moore, R.C. (ed.) Treatise on Invertebrate Paleontology. Part O. Arthropoda 1. Geological Society of America \& University of Kansas Press, Lawrence.

Whittington, H.B. 1988. Hypostomes and ventral cephalic sutures in Cambrian trilobites. Palaeontology 31(3), 577-609.

Whittington, H.B. \& Kelly, S.R.A. 1997. Morphological terms applied to Trilobita, 313-330. In KAESLER, R.L. (ed.) Treatise on Invertebrate Paleontology. Part O. Arthropoda 1. Trilobita, revised. Volume 1. Geological Society of America \& University of Kansas Press, Lawrence. 